\title{
Yield Gaps in Black Gram (Vigna mungo L) under Rainfed Farming Situations in Mandi District of Himachal Pradesh, India
}

\author{
D. S. Yadav*, Pankaj Sood, L. K. Sharma, Shakuntla Rahi and Kavita Sharma \\ CSKHPKV, Krishi Vigyan Kendra, Mandi Himachal Pradesh-175019, India \\ *Corresponding author
}

\section{A B S T R A C T}

\begin{tabular}{|l|}
\hline K e y w o r d s \\
Black gram, \\
CFLDs, Extension \\
gap, Technology \\
gap, Technology \\
index, Water use \\
efficiency
\end{tabular}

The study assessed the yield gaps in black gram (Vigna mungo L) under rainfed farming situations in Mandi district of Himachal Pradesh. A total of 224 demonstrations covering 60.60 ha area were conducted consecutively for four years under Cluster Front Line Demonstrations (CFLDs) programme during kharif 2015 to kharif 2018. Improved cultivars of black gram viz. Palampur 93, Him Mash1, Pant U 19, and UG 218 were demonstrated along with integrated crop management technologies. The study revealed a statistically significant difference in mean seed yield between demonstration plot and farmer's plot in all the demonstrated cultivars during all seasons under study. Overall, seed yield of $611 \mathrm{Kgha}^{-1}$ with 22.69 percent higher productivity and average profitability of Rs. $30,264 \mathrm{ha}^{-1}$ was obtained under the demonstration plot in the pooled data over the farmer's practice. The technology and extension yield gap in pooled data under the four-year CFLDs programme was $874.18 \mathrm{Kgha}^{-1}$ and $124.91 \mathrm{Kgha}^{-1}$ respectively. The use of high yielding varieties with improved technology packages also enhanced water use efficiency. Overall technology index of 55.56 percent revealed satisfactory performance of technological interventions which can be further boosted in the region by bridging the gaps with more efficient research and extension services.

\section{Introduction}

Crop yield gap assessment is crucial for framing appropriate policies for research and extension systems. Based on the identified gaps, extension workers can provide necessary guidelines to farmers for making rational decisions. Biophysical, management, socio-economic, institutional/policy, etc. are the contributing factors responsible for the crop yield gaps, and narrowing these gaps can improve the efficiency of land and labour resources, reduce production cost, and increase the sustainability (Yadav et al., 2018). Various researchers have described different types of crop yield gaps in different ways. Gomez et al., (1979) identified two kinds of yield gaps between experiment station and farmers' fields, of which Gap 1 is due to environmental differences while Gap 2, is the difference between potential and actual farmer yields. This gap 2 also known as the true research-extension gap mainly attributed to combinations of biological, technical, and socio-economic constraints. Evenson (1997) described three types of yield gaps namely 
extension gap i.e. the difference between best practice and average yields; the research gap i.e. the difference between research potential yields and best practice yields and science gap i.e the difference between science potential and research potential yields. Hence, complete knowledge and understanding of the factors responsible for these gaps is vital to minimize gaps and maximize the crop yields.

India is the largest producer and consumer of black gram (Vigna mungo L) in the world (Singh et al., 2017). Black gram commonly known as ' $u$ rad' is one of the important pulse crops of India. During 2017-18 it was cultivated in an area of 5.44 Million ha with a production of 3.56 Million tons at a productivity level of $655 \mathrm{Kg} / \mathrm{ha}$ (Tiwari and Shivhare, 2018) and contributed 13.73 percent in the total pulse production in the country (Anonymous, 2019). Madhya Pradesh, Uttar Pradesh, Rajasthan, Maharashtra, Tamilnadu, Andhra Pradesh, Jharkhand, Karnataka, Gujarat and West Bengal are the major black gram growing states of the country contributing more than 90 percent of black gram production (Anonymous, 2018).

Pulse cultivation has not been viewed as a profitable farm enterprise in the recent past in the state of Himachal Pradesh though it has several advantages in a sustainable production system. These leguminous crops are suitable for intercropping with different crops resulting in increased production apart from enriching soil nitrogen and improving the soil fertility (Singh et al., 2017). In spite, various factors like rainfed farming, cultivation on marginal lands, non-adoption of high yielding varieties, etc. are responsible for their low productivity (Choudhary, 2013, Kumar et al., 2015). Pulse cultivation has assumed special significance owing to the state Government's focus on Natural Farming where pulses are an integral part of cropping systems. To increase the acreage and productivity of pulses in the state in general and Mandi district in particular, the Indian Council of Agricultural Research, New Delhi has given the task to upscale the improved pulse production technology along with best practices among farmers through KVKs. Henceforth, KVK, Mandi Himachal Pradesh took initiative in this regard and up-scaled the improved cultivars of black gram which is a major pulse crop of the state with best practices of integrated crop management technologies in the district through a cluster approach. In the present paper, technology and extension yield gaps have been identified which will be useful for framing up of strategies for further intensification of the acreage of black gram cultivation in the region.

\section{Materials and Methods}

The study was conducted in Mandi district of Himachal Pradesh under rainfed farming situations during kharif season 2015 to 2018. A total of 224 demonstrations in 60.60 ha area were conducted consecutively for four years covering 116 villages of 25 clusters. Improved cultivars of black gram along with integrated crop management practices were demonstrated under CFLD plots while adjoining farmers fields where the crop was grown as per the farmer's practices were taken as farmer practice/local check (Table 1). The data on seed yield under demonstration plot as well as the farmer's plot was collected and analyzed. To analyze the difference in mean seed yield between demonstration plot and farmer's plot, Fisher's Least Significant Difference (LSD) test was employed (Yadav et al., 2018).

$\mathrm{LSD}_{0.05}=\sqrt[t]{\operatorname{MSW}\left(\frac{1}{N 1}+\frac{1}{N 2}\right)}$

Where; $\mathrm{t}=$ Critical value from $\mathrm{t}$ distribution table, MSW = Mean square within, obtained from the results of the ANOVA test, 
$\mathrm{N}_{1}=$ Number of observation of the first group,

$\mathrm{N}_{2}=$ Number of observation of the second group,

Likewise, increase in seed yield in the demonstration plot over farmers' practice was worked out as per the formula earlier used by various researchers (Choudhary et al., 2009; Yadav et al., 2017, 2018):

Increase in yield over farmer's practice $($ YIOFP, \%) $=$

Demonstration Plot Yield (DPY)- Farmers Plot Yield (FPY) Farmers Plot Yield (FPY) $\mathrm{x} 100$

Technology gap, extension gap and technology index was worked by the following formulae as earlier used by various researchers (Samui et al., 2000; Kadian et al., 1997; Dwivedi et al., 2014; Yadav et al., 2018):

Technology gap $\left(\mathrm{kg} \mathrm{ha}^{-1}\right)=$ Potential Yield (PY) - Demonstration Plot Yield (DPY)

Extension gap $\left(\mathrm{kg} \mathrm{ha}^{-1}\right)$

$=$ Demonstration Plot Yield (DPY) - Farmer's Plot Yield (PPY)

Technology Index $(\mathrm{TI} \%)=\frac{\text { Potential Yield (PY) }- \text { Demonstration Plot Yield (DPY) }}{\text { Potential Yield (PY) }}$

\section{Economic analysis of CFLD's}

Under demonstration plot, the cost of seed of improved varieties, recommended fertilizers, seed treatment with fungicide and seed inoculums with biofertilizers (Rhizobium and PSB), herbicide, pesticide, etc. were either supplied to the farmers by KVK or invested by farmers were included for calculating the cultivation cost. Under farmer's practice, it included the cost of inputs purchased by the farmers, and accordingly gross and net returns were worked by using the standard formula
(Choudhary et al., 2009; Yadav et al., 2017, 2018).

\section{Water use and water use efficiency}

Water use and water use efficiency was worked out by adopting the method of Choudhary et al., 2009 and Choudhary, 2013. The seasonal water use (Et) is computed from profile water contribution (CS), effective rainfall (ER) and irrigation water applied (I) using the equation: $\mathrm{Et}=\mathrm{CS}+\mathrm{ER}+\mathrm{I}$. The profile water contribution (CS) was not considered both in demonstration plots and farmers' plots due to the varying agroecological conditions. Thus, water use efficiency was worked out by taking in to account the effective rainfall received during the crop growth period, and rainfall data from the Agrometeorological Observatory of KVK Mandi was used for this purpose.

\section{Results and Discussion}

\section{Seed yield under black gram cultivars}

The data concerning the performance of black gram cultivars demonstrated under CFLDs have been presented in Table 2 . The results given in Table 2 revealed that black gram cultivar Palampur 93 provided the highest seed yield of $709 \mathrm{Kgha}^{-1}$ under demonstration plot during kharif 2015 which was 20.17 percent higher than the farmer's practice. This variety was further demonstrated during kharif 2016 to kharif 2018 in an area of 20.25 ha covering 68 demonstrations and provided the seed of $594 \mathrm{Kgha}^{-1}, 662 \mathrm{Kgha}^{-1}$ and 520 $\mathrm{Kgha}^{-1}$ respectively. Likewise, 92 demonstrations on improved variety of black gram Him Mash 1 was conducted under CFLD programme consecutively for three years during kharif 2016 to kharif 2018 covering an area of 25.35 ha where this variety performed well and provided additional yield advantage to the tune of 11.96 to 31.57 percent (Table 2). The data 
also revealed that UG 218 variety of black gram provided seed yield of 697,691 , and $565 \mathrm{Kgha}^{-1}$ during kharif 2016 to kharif 2018 respectively which was 25.56 to 36.67 percent higher against the farmer's practice. Overall, seed yield of $611 \mathrm{Kgha}^{-1}$ was obtained under the demonstration plot in the pooled data which was 22.69 percent higher than the farmer's practice. Fisher's least significant difference (LSD) test revealed that the difference in mean seed yield between demonstration plot and farmer's plot was statistically significant in all the demonstrated cultivars during all seasons under study. This indicates the superiority of the demonstrated technology over the farmer's practice. Further, adoption of complete integrated crop management practices might be another reason for the visible impact on enhanced seed yield under demonstration plot which otherwise was lacking under farmer's traditional system of cultivation. Seed inoculation with biofertilizers like Rhizobium and PSB culture was another major success factor of higher seed yields under demonstration plot as yield enhancement in pulses through bio inoculation with microbial cultures (Rhizobium and PSB) has also been reported earlier by various workers (Rathore et al., 2007; Kant et al., 2016). Blister beetle Mylabris species is a major pest of this crop especially at the flowering stage causing huge losses and farmers mostly ignore the pest due to lack of knowledge and awareness and reluctancy to use insecticides in black gram crop. In the demonstration plots, not only the farmers were educated about the identification of the pest but also provided with critical inputs for effective management of this pest consequently resulting in higher yields. The yield enhancement through the adoption of improved farm technology has also been reported in earlier studies of FLDs' by various workers (Choudhary, 2013; Kumbhare et al., 2014; Kumar et al., 2015; Singh et al., 2015; Jayalakshmi et al., 2018; Saikia et al., 2018).

\section{Economic analysis}

The economic analysis of black gram cultivars demonstrated under CFLDs has been presented in Table 3 and results revealed that the highest net returns of Rs. 34,590 ha ${ }^{-1}$ was obtained under black gram cultivar Pant U 19. The black gram cultivar UG 218 demonstrated under CFLDs recorded the second rank in terms of net returns (Rs. 32007 $\mathrm{ha}^{-1}$ ) followed by Palampur 93 (Rs. 27,943 $\mathrm{ha}^{-1}$ ) and Him Mash 1 (Rs. 26,517 ha $\mathrm{ha}^{-1}$. Overall, pooled data indicated the average net returns of Rs. 30,264 $\mathrm{ha}^{-1}$ as against the average net returns under farmer's practice (Table 3). Higher returns in the demonstration plot than the farmer's practice might be attributed due to the adoption of improved technologies demonstrated through CFLDs. Earlier, various workers also reported the enhanced monetary benefits by the use of improved farm technology in various crops under FLDs/CFLDs (Choudhary 2013; Kumar et al., 2015; Ganga Devi et al., 2018; Singh et al., 2018).

\section{Technology and extension gap}

The results for technology and extension yield gaps have been given in Fig 1. The technology gap in black gram cultivars Palampur 93, Him Mash 1, UG 218 ranged between 791-980 $\mathrm{Kgha}^{-1}$, 829-972 $\mathrm{Kgha}^{-1}$ and 903-1035 $\mathrm{Kgha}^{-1}$ during the period under study respectively. The highest technology gap of $1035 \mathrm{Kgha}^{-1}$ was observed in UG 218 during kharif 2018 while it was lowest during kharif 2016. In the case of Him Mash 1, the highest technology gap (972 $\mathrm{Kgha}^{-1}$ ) was observed during kharif 2018 while lowest during kharif 2017 (829 $\mathrm{Kgha}^{-1}$ ). Likewise, the highest technology gap of $980 \mathrm{Kgha}^{-1}$ was observed in black gram cultivar Palampur 93 during kharif 2018 followed by $906 \mathrm{Kgha}^{-1}$ during kharif 2016 while the lowest during kharif 2015 (Fig. 1). The study also revealed 
that the lowest technology gap was observed in Pant U 19 cultivar of black gram which was only demonstrated during kharif 2016. The overall technology gap based on pooled data for four years CFLDs programme was 874.18 $\mathrm{Kgha}^{-1}$. Various biophysical factors like dissimilarity in the soil fertility status, unfavorable microclimatic conditions, and specific crop management problems might be the reason for technology gaps which necessitated adoption of location-specific management strategies to reduce these yield gaps. These results are in support of the findings of various workers in the earlier studies (Choudhary, 2013; Kumar et al., 2015; Ganga Devi et al., 2018, Singh et al., 2018).

The results concerning the extension gap have also been depicted in Fig 1. The study revealed that the extension gap in black gram cultivar Palampur 93 ranged between 70-152 $\mathrm{Kgha}^{-1}$ during kharif 2015 to kharif 2018. In this variety, the highest extension gap of 152 $\mathrm{Kgha}^{-1}$ was found during kharif 2017 followed by kharif 2015 (119 $\left.\mathrm{Kgha}^{-1}\right)$. The highest value $\left(161 \mathrm{Kgha}^{-1}\right)$ for extension gap in black gram cultivar Him Mash 1 was observed during kharif 2017 with a minimum gap of 61 $\mathrm{Kgha}^{-1}$ during kharif 2016. Black gram cultivar UG 218 recorded the highest extension gap of $187 \mathrm{Kgha}^{-1}$ during kharif 2016 followed by kharif season 2017 and 2018 respectively. Overall, the extension gap of $124.91 \mathrm{Kgha}^{-1}$ was observed in the pooled data indicating lack of awareness on the part of farmers. Since, extension gaps are the indicators for the non adoption of improved technologies, hence an effective extension service is required to narrow the gap between research findings and farmers fields (Evenson, 1997; Oladele, 2004). It therefore strongly draws the attention of the extension system to educate the farmers by using innovative extension methods by supplying quality seeds of improved varieties besides ensuring essential critical inputs to reduce these gaps. These findings are also supported by various workers (Kumar et al., 2015; Ganga Devi et al., 2018; Singh et al., 2018; Yadav et al., 2018).

\section{Technology index}

The success of any technology depends upon its feasibility under location-specific agroclimatic conditions for its large scale diffusion (Kumari et al., 2007; Choudhary 2013; Kumar et al., 2015; Yadav et al., 2018). Lower value of technology index refers to more feasible technology and vice versa. The results depicted in Figure 2 revealed that the technology index of the demonstrated cultivars of black gram under the CFLD programme ranged between 43.67 to 60.67 percent which indicated the satisfactory performance. The reason for better performance is that these cultivars are recommended for cultivation in the state by CSKHPKV Palampur and are well acclimatized in the microclimatic conditions of the state in general and district Mandi in particular. Overall, a technology index of 55.56 percent observed in pooled data showed the satisfactory performance of technological interventions and scope for large scale adoption in the area. Earlier, various researchers have also reported the similar type of findings in their studies (Kumar et al., 2015; Ganga Devi et al., 2018; Singh et al., 2018).

\section{Water use and water use efficiency}

The rainfall pattern during the cropping season under different years has been depicted in Fig. 3. The data on seasonal water use revealed the lowest value of $548 \mathrm{~mm}$ during kharif 2015 and maximum (1097.70 $\mathrm{mm}$ ) during kharif 2018 (Table 4). Overall, seasonal water use of $789.48 \mathrm{~mm}$ was observed in the pooled data during the period 
under study. The water use efficiency (WUE) varied between 0.48 to $1.29 \mathrm{kgha}^{-1} \mathrm{~mm}$ under demonstration plots in the present study. The overall WUE observed as $0.77 \mathrm{Kgha}^{-1} \mathrm{~mm}$ under demonstration plot in the pooled data was higher than the farmer's plots. Recommended package of improved farm practices demonstrated under the demonstration plot might have improved the WUE over farmers' plots though the crop water use was the same under both the situations. A similar type of findings was also earlier reported by Choudhary (2013) and Kumar et al., (2015).

Table.1 Detail of technology demonstrated under CFLDs on black gram and farmers practice

\begin{tabular}{|c|c|c|}
\hline Particulars & $\begin{array}{l}\text { Technology demonstrated } \\
\text { under CFLDs }\end{array}$ & $\begin{array}{l}\text { Farmers practice } \\
\text { (Local check) }\end{array}$ \\
\hline Variety & $\begin{array}{l}\text { Palampur 93, Him Mash 1, Pant U 19, } \\
\text { UG } 218\end{array}$ & Mixture/local \\
\hline Seed rate & $20 \mathrm{Kg} \mathrm{ha}^{-1}$ & $30 \mathrm{Kg} \mathrm{ha}^{-1}$ \\
\hline Seed treatment & Rhizobium + PSB & -Nil- \\
\hline Sowing method & Line sowing $(30 \times 10 \mathrm{~cm})$ & Broadcasting \\
\hline Fertilizer dose & 20:40:20 Kg NPK ha ${ }^{-1}$ & -Nil- \\
\hline Plant protection & Need-based & -Nil- \\
\hline $\begin{array}{l}\text { Technical } \\
\text { guidance }\end{array}$ & Time to time & -Nil- \\
\hline
\end{tabular}

Table.2 Performance of black gram cultivars demonstrated under CFLDs in Mandi district of Himachal Pradesh

\begin{tabular}{|c|c|c|c|c|c|c|c|}
\hline \multirow[t]{2}{*}{ Year/Season } & \multirow[t]{2}{*}{ Variety under DP } & \multirow[t]{2}{*}{$\begin{array}{c}\text { No. of } \\
\text { demonstrations }\end{array}$} & \multirow[t]{2}{*}{$\begin{array}{c}\text { Area } \\
\text { (ha) }\end{array}$} & \multicolumn{2}{|c|}{$\begin{array}{c}\text { Yield } \\
\left(\mathrm{Kg} \mathrm{ha}^{-1}\right)\end{array}$} & \multirow[t]{2}{*}{$\mathbf{L S D}_{0.05}$} & \multirow[t]{2}{*}{$\begin{array}{c}\text { YIOFP } \\
(\%)\end{array}$} \\
\hline & & & & DPY* & FPY** & & \\
\hline Kharif 2015 & Palampur 93 & 12 & 1.0 & 709 & 590 & 79.75 & 20.17 \\
\hline \multirow[t]{4}{*}{ Kharif 2016} & Palampur 93 & 37 & 9.0 & 594 & 510 & 42.31 & 16.47 \\
\hline & Him Mash-1 & 32 & 7.0 & 571 & 510 & 43.13 & 11.96 \\
\hline & Pant U-19 & 13 & 2.0 & 676 & 510 & 94.27 & 32.55 \\
\hline & UG-218 & 7 & 2.0 & 697 & 510 & 141.87 & 36.67 \\
\hline \multirow[t]{3}{*}{ Kharif 2017} & Palampur 93 & 17 & 6.00 & 662 & 510 & 47.01 & 29.80 \\
\hline & Himachal Mash 1 & 39 & 12.00 & 671 & 510 & 32.08 & 31.57 \\
\hline & UG 218 & 5 & 2.00 & 691 & 510 & 127.88 & 35.49 \\
\hline \multirow[t]{3}{*}{ Kharif 2018} & Palampur 93 & 14 & 5.25 & 520 & 450 & 42.71 & 15.56 \\
\hline & Himachal Mash 1 & 21 & 6.35 & 528 & 450 & 24.70 & 17.33 \\
\hline & UG 218 & 27 & 8.00 & 565 & 450 & 28.52 & 25.56 \\
\hline 2015-2019 & Pooled data & 224 & 60.60 & 611 & 498 & 17.22 & 22.69 \\
\hline
\end{tabular}

*DPY: Demonstration plot yield; **FP: Farmers plot yield 
Table.3 Economic analysis of black gram cultivars demonstrated under CFLDs

\begin{tabular}{|c|c|c|c|c|c|c|c|c|}
\hline \multirow[t]{2}{*}{$\begin{array}{l}\text { Chickpea } \\
\text { cultivars }\end{array}$} & \multicolumn{2}{|c|}{$\begin{array}{l}\text { Average Gross } \\
\text { Cost }\left(\text { Rs.ha }^{-1}\right)\end{array}$} & \multicolumn{2}{|c|}{$\begin{array}{l}\text { Average Gross } \\
\left.\text { Return (Rs.ha }{ }^{-1}\right)\end{array}$} & \multicolumn{2}{|c|}{$\begin{array}{c}\text { Average Net } \\
\left.\text { Return (Rs.ha }{ }^{-1}\right)\end{array}$} & \multicolumn{2}{|c|}{$\mathrm{BC}$ ratio } \\
\hline & DPY* & FPY** & DPY* & FPY** & DPY* & FPY** & DPY* & FPY** \\
\hline Palampur 93 & 24425 & 22550 & 52368 & 43400 & 27943 & 21500 & 2.19 & 1.99 \\
\hline Him Mash 1 & 26583 & 24800 & 53100 & 44100 & 26517 & 20167 & 2.00 & 1.78 \\
\hline Pant U 19 & 26250 & 24800 & 60840 & 45900 & 34590 & 22400 & 2.31 & 1.85 \\
\hline UG 218 & 26583 & 24800 & 58590 & 44100 & 32007 & 20167 & 2.20 & 1.78 \\
\hline Pooled data & 25960 & 24238 & 56224 & 44375 & 30264 & 21058 & 2.18 & 1.85 \\
\hline
\end{tabular}

* DPY: Demonstration plot yield; **FPY: Farmers plot yield

Table.4 Seasonal water use and water use efficiency under CFLDs on black gram in Mandi district of Himachal Pradesh

\begin{tabular}{|c|c|c|c|c|}
\hline \multirow[t]{2}{*}{ Year/Season } & \multirow[t]{2}{*}{ Variety under DP } & \multirow[t]{2}{*}{$\begin{array}{c}\text { Seasonal water use } \\
(\mathbf{m m})\end{array}$} & \multicolumn{2}{|c|}{$\begin{array}{c}\text { Water use efficiency }\left(\mathrm{Kgha}^{-1}-\right. \\
\text { mm) }\end{array}$} \\
\hline & & & DP* & FP** \\
\hline Kharif 2015 & Palampur 93 & 548.00 & 1.29 & 1.08 \\
\hline \multirow[t]{4}{*}{ Kharif 2016} & Palampur 93 & 839.20 & 0.71 & 0.61 \\
\hline & Him Mash-1 & 839.20 & 0.68 & 0.61 \\
\hline & Pant U-19 & 839.20 & 0.81 & 0.61 \\
\hline & UG-218 & 839.20 & 0.83 & 0.61 \\
\hline \multirow[t]{3}{*}{ Kharif 2017} & Palampur 93 & 673.00 & 0.98 & 0.76 \\
\hline & Himachal Mash 1 & 673.00 & 1.00 & 0.76 \\
\hline & UG 218 & 673.00 & 1.03 & 0.76 \\
\hline \multirow[t]{3}{*}{ Kharif 2018} & Palampur 93 & 1097.70 & 0.47 & 0.41 \\
\hline & Himachal Mash 1 & 1097.70 & 0.48 & 0.41 \\
\hline & UG 218 & 1097.70 & 0.51 & 0.41 \\
\hline Average & Pooled data & 789.48 & 0.77 & 0.63 \\
\hline
\end{tabular}

* DP: Demonstration plot; **FP: Farmers plot

Fig.1 Yield gaps in black gram cultivars demonstrated under CFLDs in Mandi district of Himachal Pradesh

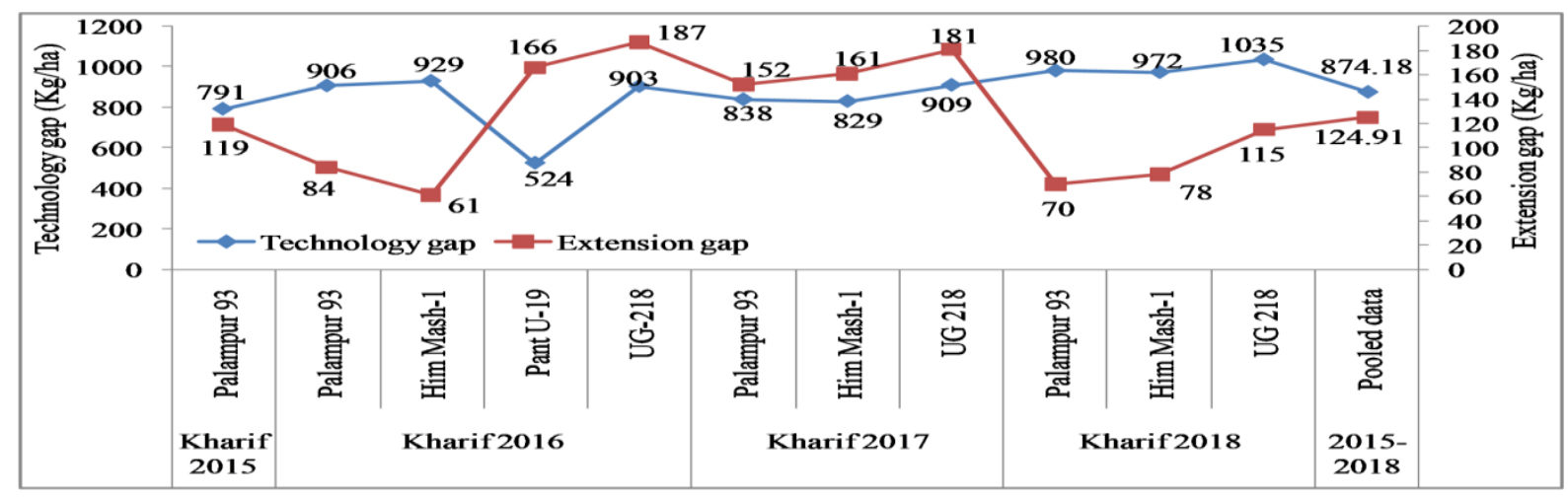


Fig.2 Technology index under different black gram cultivars demonstrated through CFLDs in Mandi district of Himachal Pradesh

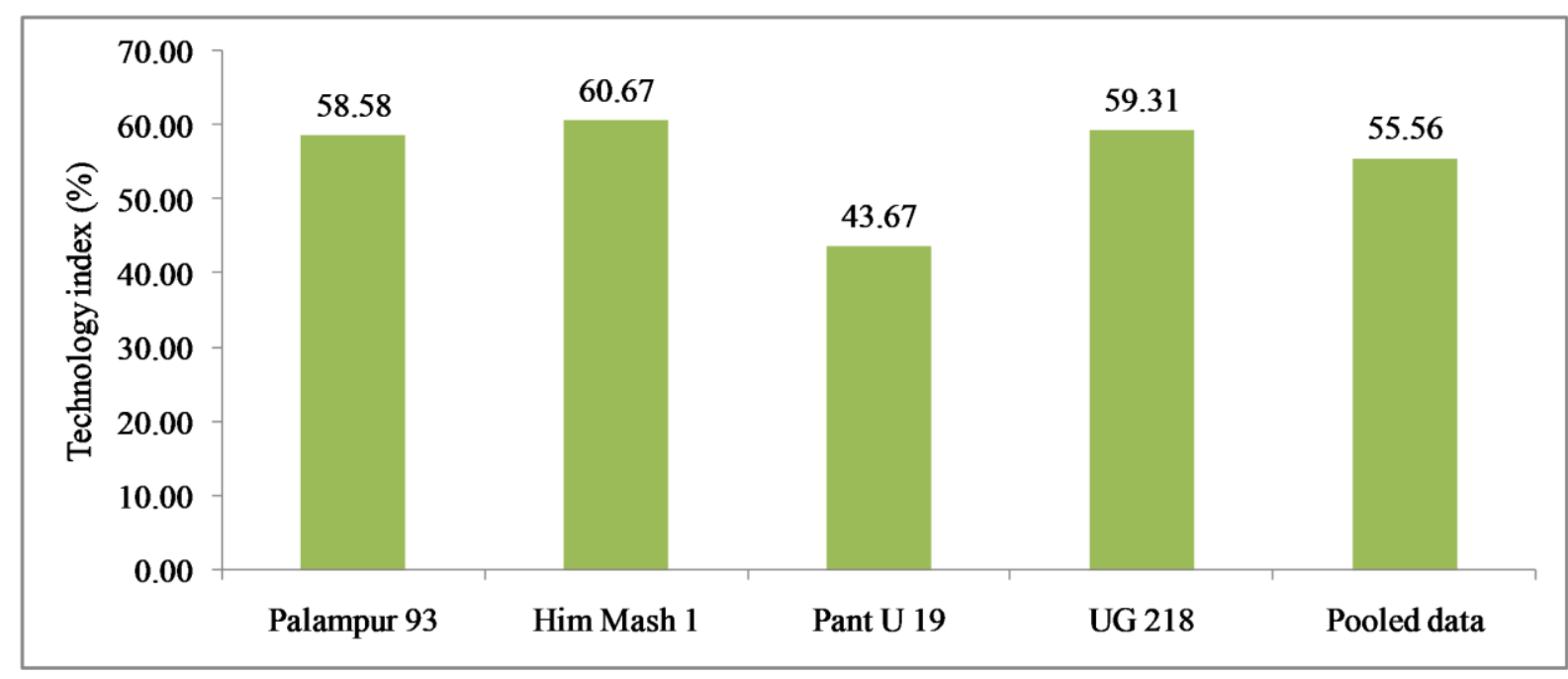

Fig.3 Rainfall pattern during the cropping season under different years of growing season

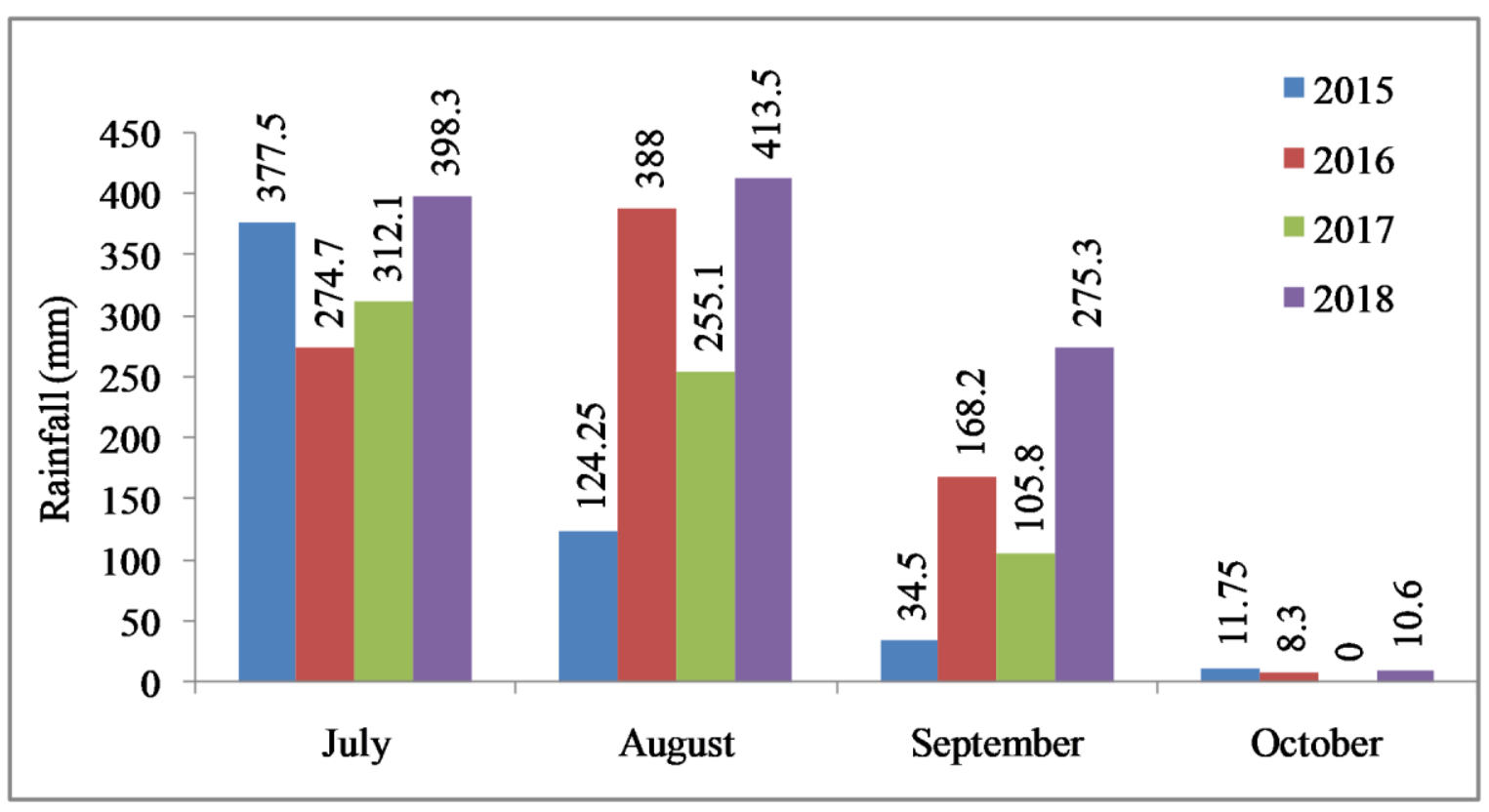

The study conclusively revealed that all the cultivars of black gram demonstrated under the CFLD programme along with integrated crop management practices increased the productivity and profitability over farmer's practice. The demonstrated technologies also enhanced the WUE even under the rainfed situations. However, some gaps mainly attributed to environmental and management factors have emerged. As environmental factors are beyond our management, there is utter need to work on management factors by deploying more efficient research and extension services to reduce these gaps to some extent. This legume crop could also be cultivated as an intercrop under natural/ organic farming systems for sustainable production in many hilly states like Himachal 
Pradesh where a rapid shift towards natural farming is being targeted by the Governments. Consequently, there is a great scope for the area expansion under this crop and therefore, extension workers should come forward to up-scale these technologies among the farmers to further intensify the black gram acreage in the region.

\section{References}

Anonymous, 2019. Commodity profile for pulses-September, 2019.

Anonymous, 2018. Pulse revolution from food to nutritional security. Crop Division, Department of Agriculture, Cooperation and Farmers Welfare, Ministry of Agriculture and Farmers Welfare, Govt. of India, Krishi Bhawan, New Delhi-110001.

Choudhary, A.K. 2013. Technological and extension yield gaps in pulse crops in Mandi district of Himachal Pradesh, India. Ind. J. Soil Cons. 41(1): 88-97.

Choudhary, A.K., Yadav, D.S. and Singh, A. 2009. Technological and extension yield gaps in oilseeds in Mandi district of Himachal Pradesh. Ind. J. Soil Cons. 37(3): 224-229.

Dwivedi, A.P., Mishra, A., Singh, S.K. and Singh, M. 2014. Yield gap analysis through front line demonstration in different agro-climatic zones of M.P. and Chhatisgarh. J. Food Leg. 27(1): 60-63.

Evenson, R.E. 1997. The economic contributions of agricultural extension to agricultural and rural development. In: Improving agricultural extension: A Reference Manual. Swanson BE, Bentz RP, Sofranko AJ (eds.). Food and Agriculture Organization (FAO), Rome, pp 27-36.

Ganga Devi, M., Ch. Anil Kumar. and Yugandhar Kumar, M. 2018. Performance Evaluation of Cluster
Front Line Demonstration in Black gram. Int. J. Curr. Microbiol. App. Sci. 7(08): 4349-4354.

Gomez, K.A., Herdt, R.W, Barker, R. and De Datta, S.K. 1979. A methodology for identifying constraints to high rice yields on farmers fields. In: Farm-level constraints to high rice yields in Asia. IRRI, Manila, Philippines, Pp. 27-47.

Jayalakshmi, M., Babu, G.P., Chowdary, K.R., Vijayabhinandana, B. and Subba Rao, M. 2018. Impact of Cluster Frontline Demonstrations (CFLDs) on Pulse Production Productivity, Profitability and Transfer of Technologies in Kurnool District of Andhra Pradesh, India. Int. J. Curr. Microbiol. App. Sci. 7(12): 937-947.

Kadian, K.S., Sharma, R. and Sharma, A.K. 1997. Evaluation of frontline demonstration trials on oilseeds in Kangra valley of Himachal Pradesh. Ann. Agril. Res. 18(1): 40-43.

Kant, S., Kumar, A., Kumar, S., Kumar, V., Pal, Y. and Shukla, A.K. 2016. Effect of rhizobium, PSB and P levels on growth, yield attributes and yield of Urdbean (Vigna mungo L). J. Pure Appl. Microbiol. 10(4): 3093-3098.

Kumar, S., Choubey, A.K. and Singh, R. 2015. Analysis of yield gaps in black gram (Vigna mungo) in district of Himachal Pradesh. Him. J. Agril. Res. 41(1): 49-54.

Kumari, V., Kumar, A., Kumar, A. and Bhateria, S. 2007. Demonstration- an effective tool for increasing the productivity of rapeseed-mustard in Kangra district of Himachal Pradesh. Him. J. Agril. Res. 33(2): 257-261.

Kumbhare, N.V., Dubey, S.K., Nain, M.S. and Bahal, R. 2014. Micro analysis of yield gap and profitability in pulses and cereals. Legume Research -An International Journal. 37(5): 532-536.

Oladele, O.I. 2004. Africa in search of 
extension system: experience from Nigeria. J. Food Agric. Environ. 2(1): 276-280.

Rathore, VS., Singh, J.P., Soni, M.L. and Beniwal, R.K. 2007. Effect of nutrient management on growth, productivity and nutrient uptake of rainfed clusterbean (Cyamopsis tetragonoloba) in arid region. Ind. J. Agric. Sci. 77(6): 349-353.

Saikia, N., Nath, K.D. and Chowdhury, P. 2018. Impact of cluster frontline demonstrations on popularization of blackgram var. PU 31 in Cachar district of Barak Valley region of Assam. J. Pharmacogn. Phytochem. 7(4): 940942.

Samui, S.K., Maitra, S., Roy, D.K., Mondal, A.K. and Saha, D. 2000. Evaluation on frontline demonstration on groundnut. J. Ind. Soc. Coastal Agric. Res. 18(2): 180-183.

Singh, D., Gill, N.S. and Singh, K.B. 2015. Yield gap analysis of cotton crop through frontline demonstrations in central plain zone of Punjab. Indian J. of Soc. Res. 56(2): 245-249.

Singh, S.K., Jakhar, K. and Singh, A.K 2017.
Study on knowledge and adoption of black gram production technology by farmers in Mirzapur district of Uttar Pradesh. Trends in Biosciences. 10(19): 3520-3523.

Singh, S.P., Paikra, K.K. and Patel, C Rani. 2018. Performance of cluster frontline demonstration on productivity and profitability of blackgram (Vigna mungo) in Raigarh District of Chhattisgarh, India. Int. J. Curr. Microbiol. App. Sci. 7(06): 1325-1330.

Tiwari, A.K. and Shivhare, A.K. 2018. Pulses in India: Retrospect and Prospects. Directorate of Pulse Development, Bhopal Ministry of Agriculture, Cooperation and Farmers Welfare, Government of India.

Yadav, D.S., Sood, P. and Sharma, L.K. 2018. Scaling-up of paddy cv. HPR 2612 (Palam basmati L) under irrigated transplanted conditions of Himachal Pradesh. J. Hill Agric. 9(3): 335-339.

Yadav, D.S., Sood, P., Sharma, L.K., Kumar, S. and Sharma, K. 2017. Yield gap analysis in Pusa Basmati 1509 in district Mandi of Himachal Pradesh. J. Hill Agric. 8(3): 334-338.

\section{How to cite this article:}

Yadav, D. S., Pankaj Sood, L. K. Sharma, Shakuntla Rahi and Kavita Sharma. 2020. Yield Gaps in Black Gram (Vigna mungo L) under Rainfed Farming Situations in Mandi District of Himachal Pradesh, India. Int.J.Curr.Microbiol.App.Sci. 9(06): 1657-1666. doi: https://doi.org/10.20546/ijcmas.2020.906.205 